\title{
How Undergraduate Academic Courses can Instill an Appreciation of Marine Ecology and Oceanography
}

\author{
John Korstad ${ }^{1 *}$, Miqueas Barreiro², LeeAnn LeMarr², Anna Bailey², Anna Christine Taylor ${ }^{2}$ and Aidan Huene ${ }^{3}$ \\ ${ }^{1}$ Department of Biology \& Global Environmental Sustainability, Oral Roberts Univ., Tulsa, OK 74171 USA
}

${ }^{2}$ Oral Roberts University, Tulsa, OK 74171 USA

${ }^{3}$ Univ. Pittsburgh, School of Medicine Starzl Transplantation Institute, USA

*Corresponding author: John Korstad, Email: jkorstad@oru.edu

Submission: 海January 31, 2019; Published: 海 February 11, 2019

\section{John Korstad's Introduction}

I have been teaching the Marine Ecology (BIO 458) course at ORU (Oral Roberts University) since its inception in 1985. Marine Ecology. lec \& lab counts as an upper division Biology course for MMB and Bio majors and fulfills the field biology requirement for Bio majors and minors. The lecture is a normal 3 credit course during every other spring semester and the lab (1 cr.) is centered around a 1 week. field trip to a marine location, which over the years has been to Key Largo or another Florida Key (5-6 times), Jamaica (3x), Belize (1x), Puerto Rico (1x), Bonaire (1x), and most commonly to Cozumel, Mexico (12x) because it's truly one of the best SCUBA diving locations in the world, it's relatively cheaper than other destinations, and we know and trust the people there who run the diving, boats, and hotel. For the lab, we encourage but don't require students to either be SCUBA-certified before going on the trip or to take the Health and Exercise Science SCUBA course beforehand at ORU.

We can do this because Michael and Lora Conte (the husbandwife team who teach the SCUBA courses at ORU) go on the trips with my class. It's been a wonderful arrangement, and they are outstanding, safe, and courteous certified SCUBA Instructors. We actually spend more than the usual 45 hrs of semester lab time doing field work like shore walks, off-shore (boat) SCUBA diving, near-shore diving or snorkeling, nightly and/or morning class lectures and discussions, student PowerPoint presentations, and group studying. The purpose of these trips is easily met to enhance student learning through an experience of studying marine ecology in the natural marine environment, and which results in a lifetime of appreciation of marine habitats, especially for those hoping for a future career in marine biology.

\section{Some Students' Comments After Going on these Trips}

Miqueas Barreiro (Mechanical Engineering major) article for the OUR 2018 yearbook based on an interview of LeeAnn LeMarr (Medical Molecular Biology major)

It's one thing to see a picture of a fish on a slideshow, but as the ORU marine ecology class found out, it is quite another thing to see it up close in real life. Over spring break, a group of 19 students traveled to Cozumel, Mexico to SCUBA dive and snorkel in the coral reef. Not only did this trip provide students with the experience of a lifetime, but it also fulfilled a class requirement for their majors.

"I wasn't expecting the parrotfish and angelfish to be so colorful," LeeAnn LeMarr, junior medical molecular biology major, said. The trip was LeMarr's first time leaving the United States and her first time on a plane and a boat. She was both excited and nervous for the trip, but her favorite part was the very first dive. "I hadn't been diving since [my training days at] Lake Tenkiller, and it was my first time in the ocean," she said. Students participated in dives during the day, and at night would meet to discuss the organisms they saw on the dives. "We saw a lot of sergeant majors," LeMarr said. "It was on my [lab] presentation, so it was cool that it was the first thing we saw." Other organisms the students saw included nurse sharks, sea turtles and eagle rays, as well as many different types of colorful fish and coral. Along with the underwater paradise experience, the students found their own inspiration from the trip.

"I am going to be a science teacher," LeMarr said. "This will help add to what I can bring to the classroom to make ecology more ..fun. "Not all the participants were Biomedical Chemistry majors. Among the other students who went to Cozumel were a studio art major, a mechanical engineering major and an elementary education major. "To anyone who is on the fence about going, I would highly encourage you to do it," LeMarr said. "It was a lot of practical knowledge and a life-changing experience."

\section{Anna Bailey ( Medical Molecular Biology major)}

I am so thankful for the opportunity I had to participate in the Marine Ecology Scuba Diving trip to Cozumel during Spring Break 2018. I think that through the shared experience between my classmates, the students from other colleges, and the faculty I was able to learn even more about the marine wildlife than what would have been possible in a classroom setting. I love SCUBA diving, and this was the perfect opportunity for me to earn my advanced certification while being proactive in my biology career. I found that I learned the material much quicker when it was swimming right in front of me. 
I truly enjoyed being able to see the marine wildlife up close and personal. The Flamingo Tongue Snail was so much smaller than expected, and the sheer amount of Long-Spined Black Sea Urchin was staggering. The larger organisms we saw included the Hawksbill Sea Turtle and a few Nurse Sharks. However, my favorite fish would have to the Black Durgon because of the graceful way it propels itself through the water with fins that ripple like the waves themselves. Not only was I able to recognize the organisms based on their familiar shape and coloration, but I could name them and then observe their behavioral patterns in their natural habitat. That isn't something you can do in an aquarium! This trip was priceless and was one of my all-time favorite experiences at ORU, and it has sparked my interest in new areas and satisfied my curiosity in others.

\section{Anna Christine Taylor (Global Environmental Sustainability major)}

Sliding down the algae covered ladder into the ocean to snorkel with friends, I watched little yellow and blue Gobies (cleaning fish) swimming all around my feet. We glided over the wall bordering the shallows; the ocean floor dropped beneath us. Sand swept under me, and fish floated far below. I swam close to the reef, watching fish dart along the rocks, the brown anemones fluttering their tentacles. Bluehead wrasses and juvenile Gray Angel Fish swam past me. Long-Spined Black Sea Urchins (Diadema antillarum ) covered the rocks. Christmas Tree worms poked out of electric green Mustard Hill Coral, Porites asteroides. I'd read about these annelids, Spirobranchus giganteus, years ago in my high school Biology textbook fascinated by the pictures of the feather duster worms and Christmas tree worms near hydrothermal vents. These worms stick their colorful filaments out of their calcium shell to filter the water and consume the debris.

The next day, after 35 minutes of driving, our snorkel boat stopped in the middle of the ocean. I donned my mask and jumped in after our guide. Brown piles of coral and rock formations rose up from the murky bottom. It was much drearier than the fantastic colors in the Finding Nemo movie. Then to my left among the sand devoid of rocks, I saw him. A sea turtle glided upwards. Movement flickered behind it. From the sand another turtle, bigger than the first rose up, hardly moving its fins. It lifted its head to the surface and glided back down. They were too far away to see the beaks, so I couldn't tell if they were Green or Hawk's Bill sea turtles. I watched them, suspended in the water. Here I had read for years about these creatures, and there they were, not behind glass, but right in front of me in the wild, in their own home.

As the current pushed me forward, I looked to my right. A raised concrete structure, which looked like a sunken wall, tilted along the sand. Two Southern stingrays, each from the opposite direction, floated along the slab. One stingray was dark, nearly black and the other white. A fish, a Bar Jack, hovered over one of the stingrays almost as if it was riding it. The next stingray drifted closer. I was astounded that another Bar Jack was riding it as well. The stingrays converged paths, missing each other by inches and both continued off the slab and along the sand, gliding further and further apart. Flipping through Dr. Korstad's Humann book afterward, I found a picture of this exact occurrence and freaked out. The Bar Jack follows the stingray, gleaning any leftover prey and helps it scour the ocean floor. This common mutualistic relationship is christened "shadowfeeding" [1]. Ironically, it wasn't trailing an enormous spotted Eagle ray or swimming with Sea Turtles and Stingrays that made this trip special to me it was the Christmas Tree Worms. Watching their delicate filaments, electric blue and red wave in the surge, not twodimensional in a textbook, but in person enchanted me. This trip showed me that science is alive all around us-sometimes we need to dive in to see it.

Aidan Huene (former undergrad Biology major at ORU who went on the 2014 Bonaire trip as a student and returned on the Mar. 2018 Cozumel trip as an alumnus and served as the SCUBA Assistant): When I first heard about the marine ecology trip my first semester at ORU, I knew I had to be on that trip. I was fascinated with the prospect of learning a new skill (SCUBA), travelling to a new place, and exploring the underwater paradise that many forget to include on their list of things to see. Getting class credit was just a bonus. I knew that SCUBA was something that I wanted to be able to do and take with me wherever I go to enjoy a whole other aspect of nature. Fast forward a couple semesters of grueling classes and exciting checkout dives for SCUBA certification and when we got to Bonaire for my marine ecology trip as a junior in my undergraduate studies, it was so much better than I could have ever anticipated. There is nothing like experiencing everything first hand. Not only were the underwater adventures the highlight of every day, but also the time we spent together sharing stories about what we saw and enjoying the company we were in made every moment of this trip memorable. It was a very supportive and collaborative atmosphere while we studied for the lab practical and the alumni and non-student participants on the trip made sure we enjoyed every moment we weren't pouring over books and pictures of organisms for the practical. Even on the last day when we couldn't dive anymore, our trip around Bonaire through Washington-Slagbaai National Park and getting to see the flamingos and different vegetation was a great way to wrap up the fantastic week of diving. Going back to the remainder of the school year was a little difficult because all I wanted to do was go back and dive.

Fortunately, four years later I was able to go on the marine ecology trip to Cozumel, Mexico with ORU again, this time as an alumni and I got to focus solely on the dives and wonderful island weather (a fantastic escape from the winter weather of Pittsburgh, PA where I study for my doctorate). There was a large group of students that had committed to the trip and it was so great to see the interest and the excitement from people who were seeing aquatic life in person for the first time. It was also a great time of fellowship and connecting with old friends and other alumni whom I had never meet and we were able to share and discuss so many interesting things about diving, marine organisms, the world, and life in general. This was the first trip that I had gotten to see sea turtles, nurse sharks, and a spotted eagle ray which was definitely 
one of the highlights of my trip. I look forward to the next time I am able to join the ORU Marine Ecology class on their next adventure!

\section{John Korstad's Summary}

I encourage students focusing on marine biology or majoring in GES (Global Environmental Sustainability) to take 2 summer courses at the Au Sable Institute of Environmental Studies (https:// www.ausable.org/college/). This is a Christian organization that is affiliated with/ the CCCU (Council of Christian Colleges and Universities) and offers excellent courses in N. Michigan (I have taught the Lake Ecology \& Management course there every summer since 1996), Washington (near Seattle-Mar. Inverts., Mar. Mammals, etc.), Costa Rico, and India. In addition to the academic courses at ORU, we have a close working relationship with/ the aquarium staff at the Tulsa Zoo since 1980 and more recently with/the OK Aquarium in Jenks since before it opened. Some of our students have done internships and/or research at both places. Three ORU students have also done 6-month internships at the Disney Epcot Center Living Seas (http://profinterns.disneycareers.com/en/ default/) and found that to be an excellent experience. Several past students conducted their Senior Research during their internship at other marine biology affiliated sites.
In addition, a few students did extra summer coursework at other universities that offer specialized training not available at ORU. One example is the Gulf Coast Research Lab Summer Field Program (http://gcrl.usm.edu/summer field/index.php). One ORU student completed her summer research internship there, which became her ORU Senior Paper. After graduating from ORU in 2016 she returned to GCRL (part of the Univ. of Southern Mississippi) for graduate school. She completed her master's degree in Oct. 2018 and has been accepted to their PhD program.

Several ORU grads currently work in the marine biology field. One finished her PhD in fish immunology and is currently teaching at a university, one worked as a veterinarian at the Boston Aquarium and is now in private practice in the Boston area, one teaches marine biology at a university in Washington State, and one works for a Florida Keys biological supply collecting company. In summary, I believe that ORU offers an excellent, broad-based curriculum in Biology that can be tailored to fit many specialties like marine biology.

\section{References}

1. De Loach N, Humann P (1999) Reef fish behavior. New World Publications, Jacksonville, Florida, Caribbean, Bahamas.
Creative Commons Attribution 4.0 International License

For possible submissions Click Here

\section{Submit Article}

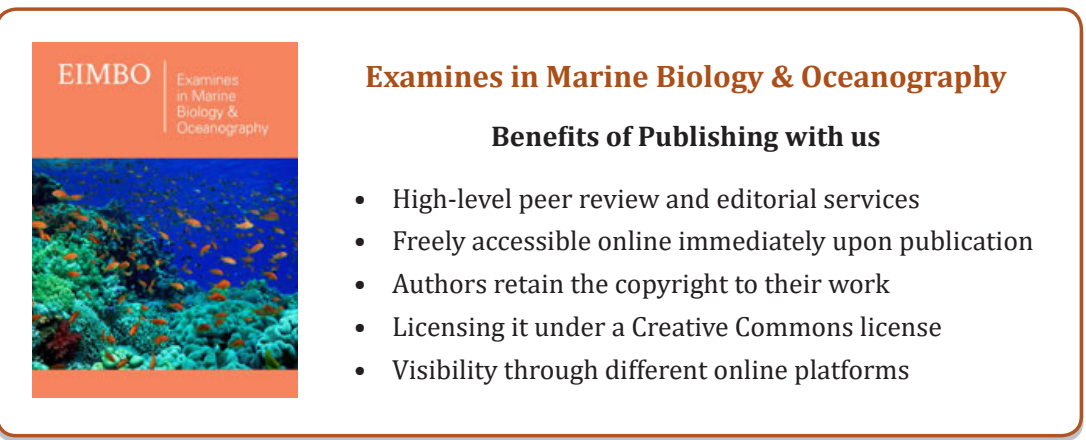

